\title{
Courtship feeding, food sharing, or tolerated food theft among paired Red-crested Pochards (Netta rufina)?
}

\author{
Juan A. Amat \\ Estación Biológica de Doñana, C. S. I. C., Apartado 1056, E-41080 Sevilla, Spain; Email: aguilar@cica.es
}

\begin{abstract}
Summary
Red-crested Pochards (Netta rufina) have been observed feeding on plants brought by their mates to the water surface, and this behaviour has been traditionally considered as courtship feeding. In this paper I report on this behaviour and examine its behavioural context. Females fed more frequently than males on plants brought by their mates to the surface, and this behaviour always occurred among paired birds. Individuals that procured the food plants were never observed offering them to their mates, but the latter simply approached the former as they surfaced with plants. The main advantages of this feeding behaviour would be to increase intake rates, as well as to reduce the feeding costs, as no time is spent searching for food underwater. Intake rates of individuals that procured the food were negatively affected when their mates profited from such food. Probably because of this, individuals that procured the food plants surfaced immediately after the feeding interaction with smaller quantities of food than before. This may be a strategy to discourage some individuals from feeding on plants brought to the surface by their mates, because this would allow the individuals that procure the food to ingest it before others start feeding on the plants. In this light, this feeding behaviour should not be considered as courtship feeding. Depending on whether pair bonds are maintained or split before breeding, this behaviour should be considered either as food sharing or tolerated food theft.
\end{abstract}

Key words: feeding interactions, food sharing, kleptoparasitism, tolerated food theft

\section{Zusammenfassung}

Balzfüttern, Teilen oder tolerierter Diebstahl von Nahrung bei der Kolbenente (Netta rufina)?

Bei Kolbenenten (Netta rufina) kann man beobachten, dass sie Pflanzen fressen, die von ihrem Partner an die Wasseroberfläche gebracht worden sind. Dieses Verhalten ist traditionellerweise als Balzfüttern bezeichnet worden. Hier werden dieses Verhalten und sein Kontext näher anlysiert. Das Phänomen trat nur unter verpaarten Vögeln auf. Die Weibchen nahmen den Männchen häufiger Nahrung weg als umgekehrt. Individuen, die die Nahrung beschafften, boten sie nie direkt ihren Partnern an, sondern die Partner näherten sich einfach den auftauchenden Vögeln. Der Hauptvorteil für die parasitierenden Vögel besteht wohl darin, dass sie ihre Nahrungsaufnahmerate vergrößern, aber dabei keine erhöhten Kosten haben, da sie für das Nahrungstauchen keine Zeit und Energie verbrauchen. Umgekehrt haben die tauchenden Partner einen Nachteil durch geringere Aufnahmeraten. Wahrscheinlich erklärt sich hieraus, dass diese, unmittelbar nachdem ihnen Nahrung weggenommen worden war, mit geringerem Nahrungsvorrat auftauchten als vorher. Dies 
könnte man als Strategie auffassen, andere Individuen davon abzuhalten, Nahrung zu stehlen. Sie wären nämlich mit dem Fressen so schnell fertig, dass ein anderes Individuum keine Zeit zum Stehlen findet.

Jedenfalls sollte diese Form des Nahrungserwerbs nicht als Balzfüttern bezeichnet werden. Je nach der Art der Paarbindung sollte man eher von Nahrungsteilen oder toleriertem Diebstahl sprechen.

\section{Introduction}

There are many situations in which an adult individual feeds on food not directly procured or found by itself, but profits from the captures or discoveries of others. These situations include courtship feeding (Lack 1940, Smith 1981), allofeeding (Woolfenden \& Fitzpatrick 1977, Collias \& Collias 1978, Senar 1984), food sharing (Wilkinson 1984, Feistner \& McGrew 1989, Rose 1997), and food usurpation (Barnard 1984, Amat 1990). Some individuals share food that they have procured with other individuals that did not cooperate with them in its acquisition (Rose 1997). This type of food sharing has been defined as "tolerated theft" by Blurton Jones (1987), and may be considered a form of kleptoparasitism (Brockmann \& Barnard 1979).

One function of courtship feeding is to provide an important source of extra nutrients for the female (Royama 1966, Tasker \& Mills 1981). Red-crested Pochard females (Netta rufina) have been observed feeding on plants brought by their mates to the water surface, and this behaviour has been considered either as food sharing (Gillham 1955) or courtship feeding (Buxton 1962, King \& Prytherch 1963, Platz 1964). These reports were mainly anecdotal and mainly involved captive birds, and few quantitative data are available on this foraging behaviour, but the interpretation of this behaviour as courtship feeding has persisted (Cramp \& Simmons 1977, McKinney 1992). Platz (1964) suggested that the main function of this behaviour was to maintain and strengthen pair bonds. In this paper I report on this behaviour in wild Red-crested Pochards, examine its behavioural context, and discuss on functional significance.

One of the factors that enable some birds to benefit from the feeding procurements of others is the long handling times of some of their food items, and this is especially evident in waterfowl bringing large food items, or large quantities of food, to the water surface to eat (Brockmann \& Barnard 1979, Amat 1990). In this study I examine whether feeding interactions among Red-crested Pochards are associated with the bringing of large quantities of plants to the water surface. I also study the extent to which this behaviour affects intake rates of the participants in this foraging interaction. If this behaviour has a negative effect on the intake rates of individuals that procure the food, then it may be expected that such individuals will adopt some behavioural strategies to counteract the negative impact (Barnard 1984), unless feeding efficiency in general is affected by the adoption of these strategies (Amat 1990). Indeed, in herbivorous waterfowl it may not pay victimised individuals to adopt evasive strategies because this would compromise their food intake (Amat \& Soriguer 1984, Amat \& Obeso 1991).

The main strategies adopted by waterfowl to reduce the impacts of food usurpation are evasive, as for example the increasing of the distance from food usurpers (Amat 1990). In the case of paired Red-crested Pochards in which one individual feeds on food procured by its mate, it may not pay the individual that procures the food to increase the distance from its mate, because as distance increases the probability of the female being harassed by unpaired males may increase (Ashcroft 1976). 
Therefore, it may be predicted that if these pochards have to stay close to their mates, their intake rates will be negatively affected.

\section{Methods}

Field work was conducted in the marshes of the Guadalquivir (SW Spain) from January to March of 1985 and 1986. The water depth at the foraging sites of Red-crested Pochards varied from $30-100 \mathrm{~cm}$. The main submerged macrophytes, upon which Red-crested Pochards fed, were Zannichellia obtusifolia, Ruppia drepanensis, Potamogeton pectinatus and, most prominently, Chara galioides. The marshes dry up in summer and flood again in autumn. However, yearly variation in the timing and amount of autumn rains modifies the extent and depth of winter flooding. Water levels were higher in 1985 than in 1986, and flooding occurred earlier in 1985 than in 1986. As a consequence submerged macrophytes developed earlier and more extensively in 1985 than in 1986.

The Red-crested Pochards foraged either by diving, up-ending, or dipping their head under water, collecting submerged macrophytes underwater and bringing the plants to the surface to eat (Amat 1984). During observation periods lasting from 2-10 min, I dictated on a small tape recorder all activities performed by a focal individual, which was chosen arbitrarily. I conducted the observations in wetlands utilized by 50-300 Red-crested Pochards. Although the birds were not marked, the probability that more than one observation was made on any one individual is low. When dictating activities, I recorded the moments when the pochard made a dive (or up-ended, etc.), surfaced and started feeding on the plants brought to the surface, stopped feeding, and dived again (or upended, etc.). In addition, the moment when any other activity was performed was also recorded, as well as the moment when another individual started to feed on plants brought to the surface by the focal individual, or the focal individual foraged on plants obtained by another pochard. When transcribing tapes, I measured the duration of each activity to the nearest 0.1 second. Red-crested Pochards were considered as paired if they were close to each other, synchronized activities, or if females incited males (Afton \& Sayler 1982, Hepp \& Hair 1984).

I only considered for analytical purposes those observation periods in which the time spent foraging by the focal bird was at least $25 \%$ of the observation time. I considered the time that the Red-crested Pochards spent feeding on the water surface as a measure of food intake, as it is probably closely related to the amount of food ingested. However, in 1986 some pochards did not bring food plants to the water surface (see below), as they were probably feeding on Scirpus seeds. I considered as searching time $\left(\mathrm{T}_{\text {searching }}\right)$ the time spent collecting food plants underwater, i. e. time diving, up-ending, or dipping head underwater. The measure of the quantity of food plants brought to the surface ( $T_{\text {plants }}$ ) was taken as the time feeding on plants actually collected by the focal Red-crested Pochard ( $\mathrm{T}_{\text {feeding }}$ ) plus the time feeding on such plants by another individual $\left(T_{\text {non-fed }}\right) . T_{\text {profiting }}$ was the time that the focal individual spent feeding on plants brought to the surface by another individual. Ingestion time $\left(T_{\text {ingestion }}\right)$ was considered either as $T_{\text {feeding }}+T_{\text {profiting, }}$ or as $T_{\text {feeding }}-T_{\text {non-fed }}$. For analytical purposes, all these times were expressed as percentages of the durations of the observation periods, and were arcsine square root transformed to meet assumptions of parametric statistical tests.

To assess the impact of foraging interactions on the food intake of birds, I compared the mean time that the pochards spent feeding on the water surface after $1-5$ dives preceding the dive after which a feeding interaction between the focal bird and another bird took place, with the mean time that the pochards spent feeding on the water surface after $1-5$ subsequent dives. The calculations on mean time spent foraging had to be done on a variable number of times because sometimes the dives after which the interaction took place occured either 
at the start or end of observations, thus limiting the number of dives available for the calculations. Furthermore, in a few cases, the foraging interaction coincided either with the start or end of observations, and in these cases I could not establish the effect of the foraging interaction on food intakes. This explains the sample size differences between analyses.

Throughout the paper mean values are presented \pm 1 s.d.

\section{Results}

In 1985 , I observed than in $42 \%$ of 26 observation periods in which a focal male Red-crested Pochard was feeding, its mate approached it and started feeding on plants brought by the former to the surface. The plants were always taken from the water surface, never from the bill of the individual that surfaced with them. Also in 1985, $4 \%$ of the focal males fed on plants brought by their mates to the surface, and in an additional $8 \%$ of the focal observations, the mates of focal males fed on plants brought by the latter to the surface, but these males also fed on plants brought by their mates to the surface during the same observation periods. Contrastingly, in $1986 \mathrm{I}$ only recorded one male feeding on plants brought by his mate to the surface, while in nine cases males did not participate in foraging interactions.

In 1985 , in $52 \%$ of 25 observation periods on focal females, these fed on plants brought by their mates to the surface. In $12 \%$ of the cases the female was approached by its mate, who fed on plants brought by the female to the surface. In 15 observation periods on focal females in 1986 I recorded no single individuals involved in foraging interactions.

In all instances this type of foraging behaviour occurred among paired individuals, and in no case did the birds which collected the plants offer them to their mates. The latter simply approached the former after a dive. Only on one occasion did a female initiate courtship after foraging on plants brought by her mate to the surface. In nine other cases in which court- ship was recorded during 30 observation periods in which foraging interactions took place, such courtship was not evidently related to one pair member feeding on plants brought to the surface by the other pair member. In three instances a male and in one instance a female moved away with food plants in its bill when its mate attempted to feed on the plants. Only in one case did I record an aggressive response of a male toward his mate when she attempted to feed on the plants he had brought to the surface.

Considering only the data of 1985 , and excluding two observation periods during which males fed on plants procured by females who in turn also fed on plants procured by their mates, the frequency with which focal females fed on plants procured by males during observation periods in which foraging interactions took place was higher than the corresponding frequency for focal males ( $G$ test: $G_{1}=16.49, p$ $<0.001$ ).

As $\mathrm{T}_{\text {plants }}$ was low in $1986(4.1 \pm 5.7 \%$ of the duration of the observation periods, $\mathrm{n}=25$ ), and feeding interactions among paired pochards were infrequent (see above), in the following only the data of 1985 are considered. There were no differences in $\mathrm{T}_{\text {searching }}$ among those Red-crested Pochards that were not involved in foraging interactions with their mates (11.2 $\pm 4.5 \%$ of the duration of observation periods, $\mathrm{n}=21$ ), those that fed on plants procured by their mates $(9.8 \pm 3.4 \%, \mathrm{n}=14)$, or those that after surfacing with food plants were approached by their mates who started feeding on the plants ("approached" hereafter; $13.6 \pm 8.7 \%, \mathrm{n}=14$; ANOVA: $\mathrm{F}_{2,46}=1.17$, $\mathrm{p}=0.321$ ). However, there were differences in the quantity of plants that paired Red-crested Pochards brought to the surface depending on whether or not they were involved in these foraging interactions. For those birds that did not participate in foraging interactions during focal observations, $T_{\text {plants }}$ was lower $(20.7 \pm$ $9.0 \%$ of the duration of observation periods, $\mathrm{n}=21$ ) than for those feeding on plants procured by their mates $(26.0 \pm 9.4 \%, n=14)$, for 
which $\mathrm{T}_{\text {plants }}$ was in turn lower than for approached pochards $(32.2 \pm 17.5 \%, \mathrm{n}=14)$. These differences were significant (ANOVA: $\mathrm{F}_{2,46}=3.59, \mathrm{p}=0.036$ ). A Tukey post hoc test on these data indicated that the only significant difference was between Red-crested Pochards not participating in foraging interactions and those approached $(p=0.028)$. Consequently, to bring large quantities of food plants to the water surface would make Red-crested Pochards susceptible to this type of foraging interaction with their mates. Indeed, the aggregate time spent foraging by both the focal host and its mate on plants collected by the former, following the dive after which the feeding interaction occurred $(24.4 \pm 20.1 \mathrm{~s}, \mathrm{n}=11)$, was longer than the mean time spent foraging by the focal bird alone after $1-5$ dives immediately preceding the dive prior to the feeding interaction occurred $(8.4 \pm 3.5 \mathrm{~s}, \mathrm{n}=9$; paired t-test: $\mathrm{t}_{8}=2.62, \mathrm{p}=0.030$ ).

However, should intake rates be affected by the participation in these foraging interactions? A comparison of $\mathrm{T}_{\text {plants }}$ (see above) and $\mathrm{T}_{\text {ingestion }}$ $(26.9 \pm 14.4 \%, \mathrm{n}=14)$ in approached individuals indicated that these birds ingested a significantly lower quantity of plants than they had brought to the water surface (paired t-test: $t_{13}=3.71, p=0.003$ ), that is, their actual $\mathrm{T}_{\text {ingestion }}$ was significantly lower than that it could potentially have been. A similar comparison for birds that fed on plants procured by their mates $\left(\mathrm{T}_{\text {ingestion }}=28.8 \pm 10.3 \%, \mathrm{n}=14\right.$ ) yielded a marginally significant result (paired t-test: $\mathrm{t}_{13}=2.09, \mathrm{p}=0.057$ ), suggesting that by feeding on plants procured by their mates, Red-crested Pochards may increase their intake rates.

As intake rates of approached Red-crested Pochards were negatively affected, should these birds adopt any evasive strategy to counteract this? In the case of focal birds that fed on plants procured by their mates, the mean time that these focal pochards spent feeding on the water surface after $1-5$ dives preceding the dive after which the foraging interaction took place $(10.0 \pm 3.7 \mathrm{~s}, \mathrm{n}=11)$ was similar to that spent feeding on the water surface after $1-5$ dives following the feeding interaction $(10.5 \pm$ $5.3 \mathrm{~s}, \mathrm{n}=10$; paired $\mathrm{t}$-test: $\mathrm{t}_{9}=0.63, \mathrm{p}=0.548$ ). Nevertheless, for approached focal birds the mean time spent feeding after $1-5$ dives preceding the dive after which the feeding interaction took place $(8.4 \pm 3.5 \mathrm{~s}, \mathrm{n}=9)$ was longer than that following the dive after which the feeding interaction took place $(5.8 \pm 2.4 \mathrm{~s}$, $\mathrm{n}=8$; paired $\mathrm{t}$-test: $\mathrm{t}_{5}=3.60, \mathrm{p}=0.016$ ). This suggests that after Red-crested Pochards had fed on plants procured by their mates, these either moved to sites where the abundance of food plants was lower, or they deliberately brought to the water surface lower quantities of food plants.

In $62 \%$ of 13 cases, focal hosts did not swim away immediately after having been approached, while in the remaining $38 \%$ of the cases they did. Owing to the small sample size, this data could not be analyzed statistically. Nevertheless, they suggest that approached birds frequently continued feeding at the same site after having been approached by their mates. Thus, the short time that approached birds spent feeding on the surface after having been approached may be a consequence of these birds deliberately bringing small quantities of plants to the surface. In the cases in which approached individuals moved away, they did this after their mates had persistently fed on plants brought to the surface by such individuals after several consecutive dives.

\section{Discussion}

Foraging by Red-crested Pochards on plants brought by their mates to the water surface was not exhibited all years, but only under conditions of abundant food. This opportunistic behaviour was employed mainly by females, and its main advantages would be to increase intake rates, and to reduce the costs of feeding, since if food is brought to the surface by others no time is spent underwater. Although traditionally considered as courtship feeding (see Introduction), this feeding behaviour does not 
actually fit the definition of courtship feeding. Courtship feeding is defined as the transfer of food from an individual to its mate, and although termed "courtship", it is not necessarily restricted to pair formation or copulation (Lack 1940, Smith 1980, Nuechterlein \& Storer 1989). In courtship feeding situations, the sex roles remain constant unlike in the Redcrested Pochard in which either sex may feed on plants procured by the other. In addition, in courtship feeding situations the individual who is fed usually begs for food, and the pair member who acquires the food never moves away with the food when its mate tries to feed on such food, as eventually Red-crested Pochards did when their mates persistently foraged on plants the former had brought to the surface. I never observed males bringing food to their mate, as Gillham (1955) did. Furthermore, during casual observations made at other southern Spanish wetlands during the breeding season (April 1988, June 1998), I never observed males offering food to their mates, who always approached males once these had surfaced with food plants.

For food to be shared, either all individuals feeding on that food should have cooperated in its acquisition, and neither individual should attempt to monopolize that food, even if food items are defensible (Blurton Jones 1987), or else individuals should sequentially exchange roles in feeding on food procured by others and in turn procuring food for themselves and others (Wilkinson 1984). Nevertheless, if food is acquired by an individual and another individual feeds on such food, without the former individual exhibiting any evasive response even if that food is easily defensible, this would be a situation of tolerated food theft (Blurton Jones 1987).

Mate switching before the breeding season may occur in ducks that pair in winter (Wishart 1983). If mate switching occurs before breeding, the foraging by Red-crested Pochards on plants brought by their mates to the water surface should ultimately be considered as tolerated food theft, as the victim would have no benefit. If, on the contrary, pair bonds are maintained until breeding, then this feeding behaviour should be considered as asymmetric sequential food sharing, since females more frequently than males feed on plants brought by their mates to the surface. In this last situation, males would benefit if their mates reach the breeding season in better condition.

Intake rates of approached individuals were negatively affected because of this type of feeding interaction. Approached individuals brought smaller quantities of food to the surface immediately after the feeding interaction than they did before. This was not a consequence of approached individuals moving to poor quality sites, but might be a strategy employed by these individuals to discourage their mates from feeding on plants they had brought to the surface. As Red-crested Pochards are more susceptible to this type of foraging interaction when they surfaced with large quantities of plants, bringing a small quantity of plants to the surface will allow an individual to ingest such plants before its mate starts feeding on them. This may be feasible if there is a "recognition delay" for birds that feed on plants procured by others once the latter surface with plants, which could give time for surfacing birds to ingest all the food (Krebs \& Inman 1992).

If food intake rates of birds that procured food are depressed, why should male Redcrested Pochards that surface with plants tolerate their mates feeding on such plants? A theoretical model on food scrounging suggests that individuals with foraging-role asymmetries should associate when the payoffs for procuring and scrounging individuals match (Barnard \& Sibly 1981). However, procurers may tolerate the presence of scroungers even if their food intake decreases, if by doing so they decrease their predation hazard (Ranta et al. 1998). In the case of male Red-crested Pochards, they should allow their mates to scrounge if by doing so interindividual distances are kept shorter than if males adopt some strategy, other than surfacing with small 
quantities of food, to diminish the risk of consumption of this food by their mates (e. g., retaliation, moving away). In this way males should spend less time interacting with other males harassing the mates of the former, which could facilitate pair bond maintainance. A similar argument was presented by Amat \& Soriguer (1984) to explain similar feeding behaviour exhibited by paired Gadwalls (Anas strepera). Nevertheless, in the less frequent cases in which Red-crested Pochards persistently foraged on plants brought to the water surface by their mates, the latter moved away. This last suggests that the feeding requirements of approached individuals are constrained in such cases, and probably because of this type of constraint, the occurrence of this feeding behaviour would be limited to conditions of abundant food.

\section{Acknowledgements}

Field work was supported by C. I. C. Y. T. project PR840243-C047-01. During manuscript preparation I was supported by D. G. I. C. Y. T. grant PB95-0110 and Junta de Andalucía (Plan Andaluz de Investigación, research group RNM 0105). I am very grateful to Pepe Clarita and the late Antonio Herrera for their assistance during field work. I thank Bart Ebbinge, Andy Green, the Editor and an anonymous referee for comments on earlier versions.

\section{References}

Afton, A. D. \& Sayler, R. D. (1982): Social courtship and pairbonding of Common Goldeneyes, Bucephala clangula, wintering in Minnesota. Can. Field-Nat. 96: 295-300.

Amat, J. A. (1984): Ecological segregation between Red-crested Pochard Netta rufina and Pochard Aythya ferina in a fluctuating environment. Ardea 72: $229-233$.

Amat, J. A. (1990): Food usurpation by waterfowl and waders. Wildfowl 41: 107-116.

Amat, J. A. \& Obeso, J. R. (1991): Black Coots (Fulica atra; Aves, Rallidae) supplanting conspecifics from foraging sites. Ethology 87: 1-8.

Amat, J. A. \& Soriguer, R. C. (1984): Kleptoparasitism of Coots by Gadwalls. Ornis Scand. 15: 188-194.

Ashcroft, R. E. (1976): A function of the pairbond in the Common Eider. Wildfowl 27: 101 - 105.
Barnard, C. J. (1984): The evolution of food-scrounging strategies within and between species. In: Barnard, C. J. (ed.): Producers and scroungers: strategies of food exploitation and parasitism: 95-126. London.

Barnard, C. J. \& Sibly, R. M. (1981): Producers and scroungers: a general model and its application to captive flocks of House Sparrows. Anim. Behav. 29: $543-550$.

Blurton Jones, N. G. (1987): Tolerated theft, suggestions about the ecology of sharing, hoarding and scrounging. Soc. Sci. Inf. 26: 31-54.

Brockmann, H. J. \& Barnard, C. J. (1979): Kleptoparasitism in birds. Anim. Behav. 27: 487-514.

Buxton, E. J. M. (1962): Courtship feeding in the Red-crested Pochard. Wildfowl 13: 170.

Collias, E. C. \& Collias, N. E. (1978): Nest building and nesting behaviour of the Sociable Weaver Philetairus socius. Ibis 120: $1-15$.

Cramp, S. \& Simmons, K. E. L. (1977): The Birds of the Western Palearctic, Vol. 1. Oxford.

Feistner, A. T. C. \& McGrew, W. C. (1989): Food sharing in primates: a critical review. In: Seth, P. K. \& Seth, S. (eds.): Perspectives in primate biology, Vol. 3: 21-36. New Dehli.

Gillham, E. H. (1955): Red-crested Pochard drakes bringing food to their mates. Brit. Birds 48: $322-$ 323.

Hepp, G. H. \& Hair, J. D. (1984): Dominance in wintering waterfowl (Anatini): effects on distribution of sexes. Condor 86: 251-257.

King, B. \& Prytherch, R. (1963): Winter feeding behaviour of Red-crested Pochards. Wildfowl 14: 172.

Krebs, J. R. \& Inman, A. J. (1992): Learning and foraging: individuals, groups, and populations. Am. Nat. 140 (Suppl.): S63-S84.

Lack, D. (1940): Courtship feeding in birds. Auk 57: 169-178.

McKinney, F. (1992): Courtship, pair formation, and signal systems. In: Batt, B. D. J., Afton, A. D., Anderson, M. G., Ankey, C. D., Johnson, D. H., Kadlec, J. A. \& Krapu, G. L. (eds.): Ecology and management of breeding waterfowl: 214-250. Minneapolis.

Nuechterlein, G. L. \& Storer, R. W. (1989): Mate feeding by Western and Clark's Grebes. Condor 91: $37-42$.

Platz, F. (1964): „Zeremonielles Füttern“ bei der Kolbenente Netta rufina. J. Ornithol. 105: 190196.

Ranta, E., Peuhkuri, N., Hirvonen, H. \& Barnard, C. J. (1998): Producers, scroungers and the price of a free meal. Anim. Behav. 55: 737-744. 
Rose, L. M. (1997): Vertebrate predation and food sharing in Cebus and Pan. Int. J. Primatol. 18: $727-765$.

Royama, T. (1966): A reinterpretation of courtship feeding. Bird Study 13: 116-129.

Senar, J. C. (1984): Allofeeding in Eurasian Siskins. Condor 86: 213-214.

Smith, S. M. (1981): Demand behavior: a new interpretation of courtship feeding. Condor 89: $291-295$.

Tasker, C. R. \& Mills, J. A. (1981): A functional analysis of courtship feeding in the Red-billed Gull, Larus novaehollandiae scopulinus. Behaviour 77: $222-241$.
Wilkinson, G. S. (1984): Reciprocal food sharing in the vampire bat. Nature 308: 181-184.

Wishart, R. A. (1983): Pairing chronology and mate selection in the American Wigeon (Anas americana). Can. J. Zool. 61: 1733-1743.

Woolfenden, G. E. \& Fitzpatrick, J. W. (1977): Dominance in the Florida Scrub Jay. Condor 79: $1-12$.

Accepted: 11 October 1999 